\title{
Invasion of Parthenium hysterophorus in the Twin Cities Islamabad and Rawalpindi
}

\author{
Hina Fatimah, Tahira Ahmad \\ Department of Environmental Science, Allama Iqbal Open University, Islamabad, \\ Pakistan \\ Email: hinafatimah@yahoo.com \\ Department of Botany, Faculty of Biological Sciences, Quaid-i-Azam University, \\ Islamabad, Pakistan \\ Email: taqau@yahoo.com
}

\begin{abstract}
Islamabad - the capital of Pakistan and its twin city Rawalpindi shows a great susceptibility to invasive species which are now threatening the native flora. A phytosociological survey was carried out to estimate the floristic composition of the two cities and to evaluate the extent of infestation by the invasive weed - Parthenium hysterophorus. The results were analyzed using TWINSPAN - an appropriate technique for hierarchical classification of community data, which resulted into formulation of six major and six minor communities. These communities were further merged to develop three overlapping vegetation zones, among which zone 1 governed completely by Parthenium hysterophorus, represented almost onethird of the entire vegetation of the study area. Parthenium with certain other invasive species as Broussonetia payrifera, Lantana camara etc. imparts serious threat to the native flora and demands immediate mitigation through integrated weed management.
\end{abstract}

Keywords: Invasive species, Invasion, Islamabad, Rawalpindi, TWINSPAN, Weeds, Weed Management.

\section{Introduction}

Biological invasions and invasive species have become issues of growing interest to many scientists during the last decades (Kubinová and Krahulec 1999, Brock et. 
al. 1997, Pyšek et. al. 1995) while the process itself represents a serious threat to native species; it also provides us with an unparallel opportunity for ecological studies (Vitousek 1990, Pyšek and Pyšek 1995).

Invasive alien species are one of the most significant drivers of environmental change worldwide (Mooney and Hobbs, 2000; Sala et al., 2000 and McNeely et al., 2001). They are not only able to affect the structure and function of an ecosystem (Vitousek and Walker 1989, Vitousek 1990) but can also reduce the biodiversity of communities and landscape both at the local and regional level (Pyšek and Pyšek 1995). They, therefore, contribute to social instability and economic hardship, consequently placing constraints on biodiversity conservation, sustainable development, and economic growth (McNeely, 2001 and McNeely et $a l ., 2001)$. The globalization of trade, travel, and transport is greatly increasing the number of invasive alien species (both individuals and species) being moved around the world, as well as the rate at which they are moving (McNeely et al. 2001). At the same time, changes in climate and land use are rendering some habitats more susceptible to biological invasion (Mooney and Hobbs, 2000). Even the most well protected natural areas are not immune to invasive alien species (Chapin et. al., 2000, Simberloff, 2000; Parkes et al., 2002; Tye et al., 2002 and O'Dowd et al., 2003).

Actual distribution of invasive species is usually supposed to be a good predictor of their invasive potential (Williamson 1996). Whether and how precisely it is possible to date of an alien species arrival to a new territory depends on how good are the relevant historic records (Pyšek and Prach, 1993). Regarding Pakistan there is no information and there has been no cataloguing of alien invasive species or their impact on the local environment. Rough estimates suggest that about 700 alien species of vascular plants are present in Pakistan, compared with about 4500 indigenous species (Khatoon \& Ali, The Herald Annual, January 1999). However, fourteen invasive plant species were initially recognized in a one-day workshop on Alien Invasive Species in Pakistan in September 1999, Islamabad and were identified as the "Species of Concern". These included Broussonetia papyrifera, Lantana camara, Prosopis juliflora, Xanthium strumarium, Cannabis sativa and Parthenium hysterophorus (IUCN 1999).

Parthenium hysterophorus, a noxious weed has invaded the federal capital and is spreading in other areas of the Punjab and North West Frontier provinces. It was reported in Islamabad for the first time in 1998 during a phytosociological survey conducted in the catchment areas of Rawal Lake that includes Islamabad as well (Fatima 1998).

Flora and vegetation in an urban environment is governed by a specific set of factors among which those imposed by man are the crucial ones (Kowarik 1990, 1991). The impact of man in large urban agglomerations and medium-sized cities is undoubtedly very strong and the pattern reflected in spatial distribution of flora is more conspicuous and can be easily determined (Mandák et. al. 1993) 
The objectives of this research were (1) To study the distribution of Parthenium hysterophorus emphasizing the twin cities Islamabad and Rawalpindi and (2) to determine the effects of human disturbance and interactions on the extent of invasion.

\section{Study Area}

It lies between $33.04^{\circ}-34.01^{\circ}$ north latitudes and $72.38^{\circ}$ and $73.37^{\circ}$ east longitudes having an area of 6,246 square kilometers. The site is a panoramic expanse of natural terraces and meadows rising from 518 to 610 metres. The climate is sub-humid to subtropical continental, receiving rainfall from both monsoon and western disturbances. The maximum rainfall occurs during the monsoon season from July to September. The average rainfall is about 1,044 millimeters per year, with more than $50 \%$ occurring in monsoon season. The mean maximum temperature ranges from $25.6^{\circ} \mathrm{C}$ to $39.4^{\circ} \mathrm{C}\left(78.1^{\circ} \mathrm{F}\right.$ to $\left.103^{\circ} \mathrm{F}\right)$ in June and the mean minimum temperature ranges from $3.2^{\circ} \mathrm{C}$ to $16.7^{\circ} \mathrm{C}\left(37.8^{\circ} \mathrm{F}\right.$ to $62^{\circ} \mathrm{F}$ ) in January. Temperatures in the study area vary from $-1.1^{\circ} \mathrm{C}$ to $46.1^{\circ} \mathrm{C}$ $\left(30^{\circ} \mathrm{F}\right.$ to $\left.115^{\circ} \mathrm{F}\right)$. The topsoil cover is formed by sandy silt in medium dense form, with varying degrees of clay content and a thickness of $1.5 \mathrm{~m}$. Silty, sandy gravel in a medium-dense to dense conditions exists below the topsoil cover of sandy silt, extending to the depth of $3.0 \mathrm{~m}$ to $5.0 \mathrm{~m}$ (EIA, 2005).

Islamabad is a modern city designed to ensure smooth and swift communication. The city is divided into eight basic zones: administrative, diplomatic enclave, residential areas, educational sectors, industrial sectors, commercial areas, rural and green areas. In contrast to the Islamabad city, Rawalpindi in unplanned and densely populated. It is the fourth largest city in Pakistan.

\section{Methods}

For the collection of vegetation data Braun-Blanquet (Blanquet, 1932) approach was used. Sampling carried out using quadrats that were not randomly located and carefully selected as representative area of a vegetation type (Kent and Cooker, 1992). Based on the usual observation of vegetation structure, which comprised mostly of herbs and grasses, the quadrat size of $1 \times 1 \mathrm{~m}^{2}$ was selected. The invasive plant species spread vigorously along the roadsides, vacant plots, wasteland etc. (Rodgers and Parker, 2003; Larson et. al., 2001; Grime, 1979 and Vartak, 1968), the road map of the two cities was thoroughly studied. Except for the streets leading to individual houses and buildings, the main roads fencing each sector and protruding midway to reach the centre of the sector from the four sides were sampled. A quadrat of $1 \times 1 \mathrm{~m}^{2}$ was laid every 100 meters on both sides of the road. Each quadrat was considered as an individual sample and the cover 
value for each species within each sample/quadrat was recorded by visual estimation and then converted to the Domin cover scale (Curral, 1987). The data collected for each stand was entered into Two-Way Indicator Species Analysis (TWINSPAN), which is an appropriate technique for hierarchical classification of community data

\section{Results}

Data collection for individual stand was made and the results were also analyzed separately. A total of 3262 quadrats were laid in which 88 species were identified. The results obtained from the TWINSPAN analysis for all the 21 stands were compared and analyzed to identify 6 major and 6 minor communities. The major communities spread over more than one stand and are formed by the fusion of data collected from various sites but exhibiting similar floristic composition. The minor communities, however, were smaller independent communities that did not match or fit into any of the major communities.

An analysis of these results obtained from TWINSPAN enabled us to divide the overall vegetation of the study area roughly into three overlapping zones. Among these a distinct zone ruled by Parthenium hysterophorus forming a strong association with Cynodon dactylon can be isolated. This zone comprising of our $4^{\text {th }}$ major community "Parthenium - Cynodon community" and spread over eight stands out of a total of twenty-one, thus representing $40 \%$ of the entire vegetation composition reported in this study. This was the largest community observed in the entire study area consisting of 1064 samples, which is approximately one third of the total samples recorded. Parthenium occurred in 762 quadrats $(71.61 \%$ occurrence) showing relative cover percentage of 24.10 (average). It formed thick continuous mats along the roadsides, which might or might not include small grassy patches covered with Cynodon and few other grass species like Brachairia and Dactyloctenium. Parthenium and Cynodon have a high degree of patchiness and form large colonies (Oudhia, 2000). This community was found spread over the recently and most disturbed patches of the urban area. It included G-10, G-11, F-11, H-10, QAU-Bari Imam (stand 19) Kashmir Highway (stand 20), etc. In addition this community has also protruded towards the well-developed older sectors like $\mathrm{H}-8$ and I- 8 sectors.

All the major and minor communities are merged to compose a so-called "Zone 2" with more than 1700 samples representing $52.79 \%$ of the overall floristic composition of the area under study. These were the stands where Parthenium hysterophorus existed often as a third dominant and intermittently as a fourth with an overall relative cover percentage of 14.49 (average). The stands included, Sectors G-8, G-9, G-10, F-6, F-8, F-9, F-10, H-8, and H-9 etc. However, this should not lead us to misinterpretation in the sense that most of these areas were governed by invasive species other than Parthenium hysterophorus in association 
to some native species like Acacia, Malvastrum coromandelianum, Cynodon dactylon, Brachairia, Dactyloctenium, etc. the invasive species included, Broussonetia papyrifera, Cannabis sativa and above all the noxious weed Lantana camara.

Throughout the fieldwork, we were able to identify a few sites only that were not prone to infestation by the weed. These were rather undisturbed patches with least human interference. These unharmed communities, though minor, were merged to compose our $3^{\text {rd }}$ Zone. Cynodon dactylon, Dicanthium annulatum, Brachairia, Dactyloctenium aegyptium, Digitaria decumbens and Malvastrum coromandelianum dominated these communities. It is worth mentioning that such ideal native associations represented only $14.6 \%$ of the entire study area.

\section{Discussion}

Many introduced plants have become naturalized and some are replacing native plant species (Franklin, 2005). Not all exotic species are considered harmful (Isaac, 2001). Invasive plants are usually characterized by fast growth rates, high fruit production, rapid vegetative spread and efficient seed dispersal and sprouting. Not being native to this area, they lack the natural predators and diseases, which would naturally control them in their native habitats (Windus, 2001). The rapid growth and reproduction of invasive plants allows them to overwhelm and displace existing vegetation and, in some cases, form dense onespecies stands (Franklin, 2005). Invasive species are especially problematic in areas that have been disturbed by human activities (Sheley et al. 1999) such as road building (Trombulak and Frissell, 2000) residential development, forest clearing, logging, grazing, mining, ditching, mowing, erosion control, and fire control activities (Simberloff, 2000). Natural disturbances, such as fires, floods, tornadoes, landslides, and tree falls also provide avenues for invasive species to get started (WGW, 2000).

Invasive exotic plants disrupt the ecology of natural ecosystems, displace native plant and animal species, and degrade our biological resources. Aggressive invaders reduce the amount of light, water, nutrients and space available to native species (Randall and Marinelli, 1996; Hobbs and Huenneke, 1992; Huenneke, 1996)) cause increased erosion (Isaac, 2001) change a population's genetic makeup; harbor plant pathogens (Franklin, 2005) and contain toxins that may be lethal to humans and other animals (Nibali and Marlatt, 2003).

Islamabad is known to exhibit natural scenic beauty where care has been taken to retain the natural topography by designing the town to comfort the environment. A green belt has been managed between every two sectors to preserve the scenic beauty and to conserve the natural resources and biodiversity. With the development of the capital city, during 1960s, the introduction of an exotic plant 
"Broussonetia papyrifera" was made to make the city greener (Mateen, 1990). This introduction is showing its adverse effects in the form of pollen allergy as a serious threat for the residents of the town. In addition to it, Lantana camara poses a second threat to the native flora and fauna by establishing thick continuous mats at various spots and eliminating the native vegetation. Parthenium hysterophorus emerged as an additional threat to the native biodiversity with its gradual appearance on the roadsides, vacant plots, and unattended lawns etc. The invasion of Parthenium hysterophorus, though not very recent, was noticed some 7-8 years back (Fatima 1998; IUCN, 1999). During this span the once rarely occurring species Parthenium has taken over a number of sites that used to be covered by various native species. An example is the constantly declining establishment of Centaurea calcitrapa L. (Purple Starthistle) and Euphorbia helioscopia (Sun Spurge) that showed a common occurrence a few years back now appears rarely (Personal observation).

It is obvious from the results that Parthenium hysterophorus has invaded the entire study area specifically those areas which have gone through recent development. The least disturbed and the recently disturbed stands have been separated into Table $3 \mathrm{a}$ and $3 \mathrm{~b}$ just by a coincidence, and a prominent difference between the relative cover percentage values $(13.7 \%$ and $22.4 \%)$ and occurrence can be observed.

The Capital Development Authority is out to give Islamabad a new face. A number of commercial, infrastructural, housing, sport and recreational projects have already been initiated (Qaiser I., The Daily DAWN April 11, 2006), among which the most important is the widening and dualization of the entire road network to accommodate heavy traffic loads. Furthermore, the capital city is a non-industrial, non-agricultural town that is mainly dependent on importing all sorts of commodities from other parts of the country. Regarding the weed, spread is mainly along roads and stock routes (Kuss et. al. 1985; Stohlgren et. al 1998; Dickens et. al. 2005). It usually spreads from mud or adhering soil by agricultural and road construction and maintenance machinery and livestock, and may possibly be dispersed to a limited extent with agricultural produce (Williamson, 1996). Once the infectant enters the metropolitan area, the sites going through development for the construction of roads, residential colonies or commercial buildings will provide an opportunity for the weed to establish. An additional advantage is the climatic and soil conditions of the affected area that suits best for invasion. The new development plan of the CDA might be an additional threat to the native biodiversity unless appropriate measures for its continuous restoration are taken. 


\section{References}

[1] Blanquet, B. J., (1932) Plant Sociology. McGraw Hill, New York and London: 48-439.

[2] Brook, J. H., M. Wade, P. Pyšek, D. Green (1997) Plant invasions: studies from North America and Europe - Bachhuys Publishers, Leiden: 223.

[3] Chapin, F. S., E. S. Zavaleta, V. T. Eviners, R. L. Naylor, P. M. Vitousek, H. L. Reynolds, D. U. Hooper, S. Lavorel, O. E. Sala, S. E. Hobbie, M. C. Mack, and S. Diaz, (2000) Consequences of changing biodiversity. Nature, 405: 234-242.

[4] Curral, J. E. P. (1987) A transformation of the Domin Scale. Vegetation, 72: 81-87.

[5] Dickens, S. J. M., F. Gerhardt and S. K. Collinge, (|2005) Recreational Portage Trails as Corridors Facilitating Non-Native Plant Invasions of the Boundary Waters Canoe Area Wilderness (U.S.A.) Conservation Biology 19: 1653.

[6] EIA, (2005) Summary Environmental Impact Assessment. [Available online form: $\quad$ www.adb.org/Documents/Environment/PAK/RawalpindiEnvironmental-Improvement.pdf.

[7] Fatima, H. (1998) A phytosociological study of the catchment areas of Rawal Lake. M. Phil Dissertation, Department of Biological Sciences, Quaid-iAzam University, Islamabad.

[8] Franklin, (2005) Invasive Exotic Plants in NC [Available online from http://www.ncwildflower.org/invasives/invasives.htm.

[9] Grime J. P. (1979) Plant strategies and vegetation processes. John Wiley, London, England.

[10] Hobbs, R. J. and L. F. Huenneke, (1992) Disturbance, diversity and invasion: Implications for conservation. Conservation Biology 6: 324-337.

[11] Huenneke, L. (1996) Ecological impacts of invasive plants in natural areas. Proceedings: Western Society of Weed Science 49:119-121.

[12] Isaac S. (2001) Chinese Privet: A Case Study of the Problem of Invasive Species [Available online from http://ecoaccess.org/info/wildlife/pubs/chineseprivet.html.

[13] IUCN, (1999) Alien invasive species of Pakistan [Available online from http://edu.iucnp.org.

[14] Kent, M. and P. Cooker, (1992) Vegetation Description and Analysis, a Practical Approach. Wiley, Chichester.

[15] Kowarik I. (1990) Some responses of flora and vegetation to urbanization in Central Europe - In: Sukopp H. et. al. (red.) Urban Ecology: 45-74, SPB Academic Publishing, The Hague.

[16] Kowarik I. (1991) The adaptation of flora to man-made perturbations - In Ravera O. (red.) Terrestrial and aquatic ecosystem perturbations and recovery: 176-184, Ellis Horwood, London. 
[17] Kubínová, D. and F. Krahulec, (1999) Phenology of Rumex longifolius: a key factor for the success of an invasive species. Preslia, Praha, 70: 339-348.

[18] Kuss, F. R., A. R. Graefe, and L. Loomis, (1985) Plant and soil responses to wilderness recreation: a synthesis of previous research. In: Lucas, R. C. Proceedings of the national wilderness research conference: current research. General technical report INT-212. U.S. Department of Agriculture Forest Service, Ogden, Utah: 129-137.

[19] Larson, D. L., P. J. Andreson and W. Newton, (2001) Alien plant invasion in mixed-grass prairie: effects on vegetation type and anthropogenic disturbance. Ecological Application, 11(1): 128-141.

[20] Mándak, B., P. Pyšek and A. Pyšek, (1993) Distribution pattern of flora and vegetation in a small industrial town: an effect of urban zones. Preslia, Praha, 65: 225-242.

[21] McNeely, J. A., H. A. Mooney, L. E. Neville, P. J. Schei, and J. K. Waage, (eds.) (2001) Global strategy on invasive alien species. IUCN, Cambridge, U.K., in collaboration with the Global Invasive Species Programme: 50.

[22] McNeely, J. (ed.) (2001) The great reshuffling: human dimensions of invasive alien species. IUCN, Gland, Switzerland.

[23] Mooney, H.. and R.. Hobbs (eds.), (2000) Invasive species in a changing world. Island Press, 38 Washington, D.C., USA.

[24] Nibali, E. and E. Marlatt, Invasive Plant Control in Maryland [Available online from http://www.agnr.umd.edu/users/hgic/pubs/online/hg88.pdf.

[25] O’ Dowd, D. J., P. T. Green, and P. S. Lake, (2003) Invasional 'meltdown' on an oceanic island. Ecology, 6(9): 812-817.

[26] Oudhia, P. (2000) Toxic effects of Parthenium leaf extracts on Aspidomorpha miliaris F. and Zonabris pustulata Thunb. Insect Environment 5(4): 168-174.

[27] Parker, J. P., N. MacDonald, and G. Leaman, (2002) An attempt to eradicate feral goats from Lord Howe Island: 233-239. In Veitch, C. R. and M. N. Clout. Turning the tide: the eradication of invasive species. IUCN Species Specialist Group. IUCN, Gland Switzerland and Cambridge, U.K. [available online from http://www.issg.org/Eradicat.html.

[28] Poff, M.T. Sykes, B. H. Walker, M. Walker, D. H. Hall. (2000) Global Biodiversity Scenarios for the Year 2100. Science, 287: 1770- 1774.

[29] Pyšek, P., K. Prach, M. Rejmanek, M. Wade (1995) Plant invasions: general aspects and special problems - SPB Academic Publishing, Amsterdam.

[30] Pyšek, P. and K. Prach, (1993) Plant Invasion and the role of riparian habitat: a comparison of four species alien to central Europe. Journal of Biogeography, 20: 413-420.

[31] Pyšek, P. and Pyšek, (1995) Invasion of Heracleum mantegazzianum in different habitats in the Czech Republic. Journal of vegetation Sciences, 6: 711-718.

[32] Randall, J. and J. Marinelli, (1996) Invasive plants: weeds of the global garden. Brooklyn Botanic Garden Club, Inc. Handbook No. 149: 111. 
[33] Rodgers, J. C. and K. C. Parker, (2003) Distribution of alien plant species in relation to human disturbance on the Georgia Sea Islands. Diversity \& Distributions, 9(5): 385.

[34] Sala, O. E., F. S. Chapin, J. J. Armesto, E. Berlow, J. Bloomfield, R. Dirzo, E. Huber-Sanwald, L. F. Huenneke, R.B. Jackson, A. Kinzig, R. Leemans, D. M. Lodge, H. A. Mooney, M. Oesterheld, N.L.

[35] Sheley, R. L, S. Kedzie-Webb and B. D. Maxwell, (1999) Integrated weed management on rangelands. In: Biology and management of noxious rangeland weeds, R. L. Sheley and J. K. Petroff. (eds.) Corvallis: Oregon State University Press: 57-68.

[36] Simberloff, D. (2000) No reserve is an island: marine reserves and non indigenous species. Bulletin of Marine Science, 66: 567-580.

[37] Stohlgren, T. J, K. A. Bull, Y. Otsuki, C. A. Villa, and M. Lee, (1998) Riparian zones as havens for exotic plant species in the central grasslands. Plant Ecology 138: 113-125.

[38] Trombulak, S. C. and C. A. Frissell, (2000) Review of Ecological Effects of Roads on Terrestrial and Aquatic Communites. Conservation Biology 14(1): 18-30. 
Table 3: ( $\mathrm{a}$ and $\mathrm{b}$ ) Times of Occurrence (OC) and Relative Cover (RC) of selected species from 20 stands

\begin{tabular}{|c|c|c|c|c|c|c|c|c|c|c|c|c|c|c|c|c|c|c|c|c|c|c|}
\hline \multirow[t]{2}{*}{$\#$} & \multirow[t]{2}{*}{ Species } & \multirow[t]{2}{*}{ Family } & \multicolumn{2}{|c|}{ G-6 } & \multicolumn{2}{|c|}{ G-7 } & \multicolumn{2}{|c|}{ G-8 } & \multicolumn{2}{|c|}{ G-9 } & \multicolumn{2}{|c|}{ G-10 } & \multicolumn{2}{|c|}{ G-11 } & \multicolumn{2}{|c|}{ F-6 } & \multicolumn{2}{|c|}{$\mathrm{F}-7$} & \multicolumn{2}{|c|}{$\mathrm{F}-8$} & \multicolumn{2}{|c|}{ F-9 } \\
\hline & & & $\mathrm{OC}$ & $\mathrm{RC}$ & $\mathrm{OC}$ & $\mathrm{RC}$ & $\mathrm{OC}$ & $\mathrm{RC}$ & $\mathrm{OC}$ & $\mathrm{RC}$ & $\mathrm{OC}$ & $\mathrm{RC}$ & $\mathrm{OC}$ & $\mathrm{RC}$ & $\mathrm{OC}$ & $\mathrm{RC}$ & $\mathrm{OC}$ & $\mathrm{RC}$ & $\mathrm{OC}$ & $\mathrm{RC}$ & $\mathrm{OC}$ & $\mathrm{RC}$ \\
\hline 1 & Cynodon dactylon & 188 & 112 & 26 & 123 & 25 & 130 & 16 & 95 & 11 & 122 & 14 & 140 & 16 & 132 & 21 & 48 & 21 & 91 & 18 & 135 & 20 \\
\hline 2 & Parthenium hyst. & 147 & 16 & 8 & 50 & 10 & 89 & 14 & 105 & 20 & 87 & 21 & 161 & 26 & 51 & 8 & 22 & 10 & 43 & 13 & 69 & 17 \\
\hline 3 & Brachairia distachya & 105 & 73 & 15 & 85 & 17 & 114 & 15 & 95 & 12 & 53 & 8 & 38 & 5 & 16 & 3 & 23 & 11 & 42 & 10 & 61 & 9 \\
\hline 4 & Malvastrum corom. & 94 & 49 & 11 & 59 & 12 & 54 & 7 & 46 & 7 & 49 & 7 & 45 & 7 & 60 & 10 & 27 & 12 & 43 & 10 & 96 & 11 \\
\hline 5 & Dactyloctenium aeg. & 52 & 54 & 12 & 47 & 9 & 28 & 4 & 8 & 1 & 6 & 1 & 21 & 3 & 47 & 8 & 17 & 8 & 7 & 2 & 26 & 4 \\
\hline 6 & Broussonetia papyrifera & 37 & 4 & 1 & 16 & 3 & 36 & 5 & 52 & 8 & 10 & 2 & 26 & 4 & 14 & 2 & 9 & 4 & 15 & 3 & 31 & 5 \\
\hline 7 & Digitaria decumbens & 34 & 15 & 4 & 20 & 4 & 45 & 6 & 20 & 3 & 30 & 2 & 5 & 1 & 9 & 1 & 12 & 5 & 20 & 5 & 20 & 3 \\
\hline 8 & Cannabis sativa & 28 & - & - & - & - & 19 & 3 & 34 & 5 & 16 & 3 & 66 & 10 & 1 & 0 & - & - & 3 & 0 & 44 & 7 \\
\hline 9 & Dicanthium annulatum & 25 & 6 & 1 & - & - & 1 & 0 & 8 & 1 & 17 & 3 & 11 & 2 & 38 & 6 & 1 & 0 & 17 & 4 & 49 & 8 \\
\hline 10 & Dalbergia sisso & 21 & 9 & 2 & 7 & 1 & 18 & 3 & 11 & 2 & 12 & 2 & 11 & 2 & 18 & 3 & 5 & 2 & 9 & 2 & 11 & 2 \\
\hline 11 & Lantana camara & 6 & 2 & 1 & - & - & - & - & - & - & 1 & 0 & 27 & 5 & - & - & - & - & - & - & - & - \\
\hline
\end{tabular}

The relative cover percentage values taken as whole numbers with decimal points removed

\begin{tabular}{|c|c|c|c|c|c|c|c|c|c|c|c|c|c|c|c|c|c|c|c|c|c|c|}
\hline \multirow[t]{2}{*}{$\#$} & \multirow[t]{2}{*}{ Species } & \multirow[t]{2}{*}{ Family } & \multicolumn{2}{|c|}{$\mathrm{F}-10$} & \multicolumn{2}{|c|}{$\mathrm{F}-11$} & \multicolumn{2}{|c|}{$\mathrm{H}-8$} & \multicolumn{2}{|c|}{$\mathrm{H}-9$} & \multicolumn{2}{|c|}{$\mathrm{H}-10$} & \multicolumn{2}{|c|}{$\mathrm{I}-8$} & \multicolumn{2}{|c|}{$\mathrm{I}-9$} & \multicolumn{2}{|c|}{$\mathrm{I}-10$} & \multicolumn{2}{|c|}{ Stand 19} & \multicolumn{2}{|c|}{ Stand 20} \\
\hline & & & $\mathrm{OC}$ & $\mathrm{RC}$ & $\mathrm{OC}$ & $\mathrm{RC}$ & $\mathrm{OC}$ & $\mathrm{RC}$ & $\mathrm{OC}$ & $\mathrm{RC}$ & OC & $\mathrm{RC}$ & $\mathrm{OC}$ & $\mathrm{RC}$ & $\mathrm{OC}$ & $\mathrm{RC}$ & OC & $\mathrm{RC}$ & $\mathrm{OC}$ & $\mathrm{RC}$ & $\mathrm{OC}$ & $\mathrm{RC}$ \\
\hline 1 & Parthenium hysterophorus & 224 & 77 & 24 & 131 & 26 & 181 & 18 & 70 & 23 & 48 & 25 & 62 & 21 & 80 & 25 & 30 & 15 & 135 & 21 & 123 & 26 \\
\hline 2 & Cynodon dactylon & 167 & 101 & 18 & 150 & 18 & 120 & 28 & 100 & 14 & 65 & 18 & 91 & 14 & 110 & 13 & 75 & 15 & 149 & 14 & 141 & 15 \\
\hline 3 & Broussonetia papyrifera & 77 & 16 & 4 & 36 & 6 & 68 & 10 & 35 & 11 & 12 & 6 & 32 & 11 & 15 & 7 & 25 & 8 & 45 & 7 & 37 & 7 \\
\hline 4 & Malvastrum coromendal. & 71 & 39 & 10 & 71 & 11 & 41 & 6 & 25 & 7 & 25 & 8 & 27 & 6 & 26 & 6 & 33 & 9 & 65 & 4 & 34 & 4 \\
\hline 5 & Cannabis sativa & 71 & 18 & 4 & 48 & 8 & 48 & 7 & 36 & 9 & 29 & 10 & 48 & 7 & 42 & 8 & 18 & 5 & 54 & 4 & 61 & 9 \\
\hline 6 & Brachairia distachya & 50 & 43 & 10 & 28 & 5 & 38 & 6 & 23 & 6 & 12 & 5 & 23 & 5 & 95 & 4 & 9 & 3 & 18 & 2 & 32 & 4 \\
\hline 7 & Lantana camara & 50 & 4 & 1 & 17 & 3 & 33 & 5 & 11 & 3 & - & - & 13 & 3 & 32 & 12 & 12 & 4 & 75 & 15 & 24 & 4 \\
\hline 8 & Dactyloctenium aegyptium & 30 & 4 & 1 & 25 & 4 & 25 & 4 & 12 & 3 & - & - & 22 & 5 & 2 & 0 & 28 & 5 & 36 & 3 & 41 & 5 \\
\hline 9 & Digitaria decumbens & 20 & 20 & 5 & 16 & 3 & 11 & 2 & 11 & 3 & - & - & 19 & 4 & 12 & 3 & - & - & - & - & - & - \\
\hline 10 & Dicanthium annulatum & 19 & 11 & 3 & 12 & 2 & 12 & 2 & 12 & 3 & - & - & 21 & 5 & 5 & 1 & 5 & 1 & 4 & 1 & 9 & 1 \\
\hline 11 & Dalbergia sisso & 13 & 6 & 1 & 11 & 2 & 4 & 1 & 5 & 1 & 7 & 3 & 6 & 1 & 6 & 1 & 3 & 1 & 8 & 1 & 7 & 1 \\
\hline
\end{tabular}


Table 1: Description of Selected Stands and Number of samples taken from each stand

\begin{tabular}{clcclc}
\hline $\begin{array}{c}\text { Stand } \\
\text { No. }\end{array}$ & Stand Description & $\begin{array}{c}\text { No. of } \\
\text { Samples }\end{array}$ & $\begin{array}{c}\text { Stand } \\
\text { No. }\end{array}$ & Stand Description & $\begin{array}{c}\text { No. of } \\
\text { Samples }\end{array}$ \\
\hline 1. & Sector G-6 & 134 & 12 & Sector F-11 & 189 \\
2. & Sector G-7 & 147 & 13 & Sector H-8 & 211 \\
3. & Sector G-8 & 195 & 14 & Sector H-9 & 121 \\
4. & Sector G-9 & 165 & 15 & Sector H-10 & 80 \\
5. & Sector G-10 & 180 & 16 & Sector I-8 & 110 \\
6. & Sector G-11 & 198 & 17 & Sector I-9 & 130 \\
7. & Sector F-6 & 164 & 18 & Sector I-10 & 108 \\
8. & Sector F-7 & 87 & 19 & Stand 19 & 280 \\
9. & Sector F-8 & 113 & 20 & Stand 20 & 170 \\
10. & Sector F-9 & 192 & 21 & Stand 21 & 160 \\
11. & Sector F-10 & 128 & Total no. of Quadrats & 3262 \\
\hline
\end{tabular}

Table 2: List of communities identified from TWINSPAN results with number. of samples against each community

\section{The major communities identified are:}

1. Cynodon - Brachairia - Dactyloctenium Community 275

2. Cynodon - Parthenium - Brachairia Community 286

3. Parthenium - Cynodon - Brachairia Community 340

4. Parthenium - Cynodon Community 1064

5. Parthenium - Cynodon - Cannabis Community 615

6. Broussonetia - Cynodon Community 180

The minor but significant communities identified are:

1. Cynodon - Brachairia - Digitaria 132

2. Cynodon - Malvastrum - Dichanthium 105

3. Cynodon - Malvastrum - Parthenium 133

4. Cynodon - Ricinus $\quad 42$

5. Lantana - Broussonetia - Cynodon 138

6. Lantana - Cynodon- Parthenium 45 